\title{
4P's and 1C of New Age Spirituality: A Holistic Marketing Review
}

\author{
Emre Basci
}

\begin{abstract}
The transformation of consumers' inner worlds through social and political factors has caused a new type of market to emerge, naturally attracting the attention of marketers over the past years. Motivated by neoliberal economic policies of our time, companies conceive spirituality as a wonder product that is sellable with high profits. In this study, the under-researched concept of contemporary spirituality, which is also called new age spirituality, is reviewed from marketing perspective. The literature research conducted on the subject, in result, draws clear boundaries of the marketing mix for new age spirituality and portrays who the spiritual consumer is. The typical spiritual consumer is appeared to be middle to high age, affluent, high-educated female who is seeking the Truth without belonging to any institutional religion.
\end{abstract}

Index Terms-Contemporary spirituality, marketing, new age spirituality, spirituality.

\section{INTRODUCTION}

From spiritual books to reiki, from candles to healing stones, new age spirituality is big business. The relatively young spiritual market promises consumers both an antidote to traditional institutional religions and wholesome answers to inquiries of existence. The transformation of consumers' inner worlds through social and political factors has caused a new type of market to emerge, naturally attracting the attention of marketers over the past years. Motivated by neoliberal economic policies of our time, companies conceive spirituality as a wonder product that is sellable with high profits. As a result, we encounter a high number of spirituality-attached products in the marketplace by a few industries such as education, health-care, tourism, and counseling.

While the term spirituality is still a controversial and vague concept, it is generally defined in variations of two distinctive patterns by scholars. The first is the standardized form of religion handed down by religious authorities; the second, on the other hand, is more of a highly individualistic way of belief system [1]. This paper is focusing on the latter since the contemporary spiritual consumer seems to inhabit the second territory, which is different from that of structured religions and cults. Hence, Myers' explanations [2], "a continuing search for meaning and purpose in life; an appreciation for the depth of life, the expanse of universe, and natural forces which operate; a personal belief system", seems to appropriately define the conception of new age spirituality.

Manuscript received January 10, 2014; revised March 13, 2014.

Emre Basci is with the Anadolu University of Eskisehir, Turkey (e-mail: emrebasci@gmail.com).
This term not only excludes structured institutional teachings of religions and cults but also fictitious and superstitious beliefs that are known to be unreal. Furthermore, this concept does not embrace alternative and supernatural spiritualties such as astrology, tarot and psychic practices that are generally perceived as fabricated. In brief, as Van der Veer [3] states, "[new age] spiritualism [is] seen as a secular truth-seeking, experimental in nature and opposed to religious obscurantism and hierarchy."

In the following sections, firstly the emergence of new age spirituality in social, political, economic and historical context is to be given, and then an authentic classification in respect to capitalism will be provided to the reader, and two categories lying in the cross-section of new age spirituality and marketing will be examined accordingly. This kind of a holistic review seems necessary and critical as this phenomenon is expected to grow and spread over the globe in a fast pace.

\section{The Emergence of NeW Age Spirituality AND SPIRITUAL MARKETING}

As it is already known, new phenomena cannot be contemplated free of economic, social and political context of their time. The concept of new age spirituality and its marketing are known to have originated from the West, and the most important milestones yielding to the emergence of these are summarized as follows [3]-[9]:

1) While the eighteenth century Enlightenment challenged the authority of the Church in the West, the Romanticism movement of the same era emerged in reaction to pure scientific rationalism. And the rise of technology that originates in the Industrial Revolution of the nineteenth century supported the process of industrialization and capitalization. Moreover, at the end of the nineteenth century the eastern traditions were discovered in the West, leading to a new way of interpretation of religion.

2) The Second World War triggered the emergence of the postmodern philosophy of 1950s in France that had a considerable influence on western societies through opinion leaders. The counter-cultural movements of 1960s and 1970s in the United States and Europe supported values of freedom and individualism with the notion of breaking free from the hegemonic powers including traditional religion institutions.

3) The western neoliberal governments (e.g. the Reagan government in the US and Thatcher government in the UK) spread their first seeds of capitalism and globalization across the world, and the collapse of the Berlin Wall in 1989 proved capitalism to be the 
dominant economic and political phenomenon of thenext century. With the development of organizations founded in 1990s such as the World Trade Organisation (WTO), capitalism became more institutionalized and global. Moreover, advancements in communication and travel technologies assisted the capitalization and globalization process to a great extent.

4) The trend of consumerism and individualism in the western society has created a new path for marketing. Brands and images have started becoming more important than product functionality, and this shift in the marketing philosophy made the spirituality more sellable as a product. And more importantly, as the role of traditional religious institutions diminished, brand-new concepts such as new age spirituality emerged to fill the void.

5) Finally, the growing market of spiritual goods, services, events, places and even people directed to individualized, secularized and socially-competitive consumers has been proven to be feasible and lucrative in the new millennium. Whereas religion has been conceived as a taboo, the use of spirituality has been well received by consumers.

\section{Types OF NeW Age SPIRITUALtiES}

Carette and King [6] present 4 distinct types of spiritualties in respect to the neo-capitalistic era we are living in. Even though the authors take the concept of spirituality as a mixture of religious and spiritual aspects, the author of this paper will serve his classification by taking only the conception of new age spirituality into account. The first two categories on this classification (provided on Table I) are known to have spiritual members who are not highly involved with the spiritual market. The next duo, contrarily, seems to be pretty interested in spiritual products, qualifying for becoming the main subject of this paper.

\section{A. Anti-Capitalist and Reformist Spiritualties}

Some people commit altruistic activities just for feeling responsible, self-conscious and mature world citizens, and this attitude appears to be related with their intrinsic mindset. According to a recent study conducted by Stillman et al. [10], a spiritual set of values tends to reduce conspicuous consumption. Shaw and Thomson [11] similarly contend that spiritual values are a critical factor for ethical consumption. Pace [12] examines the effects of Buddhist ethics on materialism and finds negative correlation between two variables. These studies indicate that consumers with spiritual values are likely to be sensitive toward social/environmental problems and critical of excesses of life served by hegemonic powers of capitalism. Yet, whereas these particular segments appear to be spiritual, they do not look eager for the spiritual market, proving that being spiritual does not necessarily lead to consuming spiritual goods and services.

\section{B. Consumerist and Capitalist Spiritualties}

Some leading keywords defining consumerist spiritualties are 'lifelong learning', 'seeking', 'journey' and 'turn to the self' [13]-[15]. Such an ongoing exploration for the meaning in life and the Beyond, a universal creator, lets individuals to experiment with philosophies that resonate with them [16], explained by Davie [7] as "believing without belonging". As Rindfleish [15] states, the products of new age spiritualism tend to be different combinations of eastern and western traditions and scientific practices and theories, altogether serving unique meta-theories to the consumer. Consumerist spiritualties, in sum, appear to be bringing belief and market together. Businesses and consumers create and seek constant stimulation by marketing and consuming the spiritual utility such goods have to offer [15], [17]. Moreover, as Bruce [18] argues, new age movements generally do not seek to recruit loyal members but rather embrace a consumer mentality through the marketing of their services.

\begin{tabular}{|c|c|c|c|}
\hline $\begin{array}{l}\text { Type of } \\
\text { spiritualty* }\end{array}$ & $\begin{array}{l}\text { Distinctive } \\
\text { characteristic }\end{array}$ & $\begin{array}{c}\text { Exemplary } \\
\text { Business } \\
\text { type }\end{array}$ & $\begin{array}{l}\text { Exemplary } \\
\text { Consumer }\end{array}$ \\
\hline Anti-capitalist & $\begin{array}{l}\text { Rejects the } \\
\text { capitalist } \\
\text { ideology by } \\
\text { going against the } \\
\text { flow in } \\
\text { production or } \\
\text { consumption }\end{array}$ & Co-ops & Anti-consumerists \\
\hline Reformist & $\begin{array}{l}\text { Manufactures or } \\
\text { consumes with a } \\
\text { spiritual set of } \\
\text { values }\end{array}$ & $\begin{array}{l}\text { Green } \\
\text { companies }\end{array}$ & Green consumers \\
\hline Consumerist & $\begin{array}{l}\text { Embraces } \\
\text { consumerism and } \\
\text { individualism } \\
\text { with a spiritual } \\
\text { twist }\end{array}$ & $\begin{array}{l}\text { Companies } \\
\text { that provide } \\
\text { Tai chi } \\
\text { classes }\end{array}$ & $\begin{array}{l}\text { Consumers who } \\
\text { buy books with } \\
\text { new-age } \\
\text { spirituality theme }\end{array}$ \\
\hline Capitalist & $\begin{array}{l}\text { Exploits the } \\
\text { notion of } \\
\text { spirituality for } \\
\text { materialistic } \\
\text { benefits }\end{array}$ & $\begin{array}{l}\text { Companies } \\
\text { that use } \\
\text { spiritual } \\
\text { teachings } \\
\text { for } \\
\text { maximum } \\
\text { efficiency } \\
\text { at the } \\
\text { workplace }\end{array}$ & $\begin{array}{l}\text { Consumers who } \\
\text { buy spiritual } \\
\text { books promising } \\
\text { personal wealth }\end{array}$ \\
\hline
\end{tabular}

*Adapted from J. Carrette and R. King, \$elling Spirituality: The Silent Takeover of Religion, London and New York: Routledge, 2004.

Whereas consumerist spirituality stands for an authentic way of identity search and identity building through consumption, capitalist spiritualties represent the dark side of the market. The exploitation of spirituality for economic and personal benefits creates an unethical and oxymoron situation. A striking example is Joe Vitale, a writer and public speaker who promises his audience a quick acquisition of wealth through the positive thinking mantra of spirituality. Rita's, a company of spiritual goods, sells its 'Better Business Spiritual Mist Spray' with the tagline 'Perfect for Small Businesses', promising entrepreneurs to enlarge their start-ups by spraying the solution all around. Moreover, some businesses exploit employees by adopting spiritual work ethics only to acquire maximum efficiency at the workplace without undertaking necessary measures for employee satisfaction. For capitalist spiritualties, spirituality is just a tool for acquiring materialistic benefits. 


\section{4P'S AND $1 \mathrm{C}$ OF New Age SpIRItuality}

In this section, the marketing mix of new age spirituality will be introduced with numerous examples. E. Jerome McCarthy's prominent typology distinguishes the main aspects of marketing under four headings: Product, Price, Promotion and Place (or Distribution), which are known to be the 4P's of Marketing [19]. Robert F. Lauterborn later proposed a brand-new classification (4C's of marketing), stressing the leading role of the consumer as a result of an important shift in marketing philosophy [20]. While 4 P's and $4 \mathrm{C}$ 's in these two classifications seem to appropriately overlap with one another, they serve no adequate info about the distinctive features of the Customer. After all, marketers need to know their target customer to design their marketing efforts accordingly. Hence, in order to provide a holistic review of spiritual marketing the author combines the marketing mix with the Customer, calling it the 4P's and $1 \mathrm{C}$ examination of the concept.

TABLE II: 4P'S AND 1 C OF NEW AGE SPIRITUALITY

\begin{tabular}{|c|c|c|}
\hline $\begin{array}{l}\text { Marketing } \\
\text { mix }\end{array}$ & Distinctive characteristic & Examples \\
\hline Product & $\begin{array}{l}\text { Goods, services, places, } \\
\text { events and people }\end{array}$ & $\begin{array}{l}\text { Hand drums for } \\
\text { mediation, reiki } \\
\text { classes, the Sedona city } \\
\text { in Arizona, Mindy, } \\
\text { Body and Spirit } \\
\text { festivals, Deepak } \\
\text { Chopra }\end{array}$ \\
\hline Price & $\begin{array}{l}\text { Flexible and highly sensitive } \\
\text { to the degree of uniqueness } \\
\text { perception }\end{array}$ & $\begin{array}{l}\text { Gemstones } \\
\text { Psilomelane \& } \\
\text { Hematite for } \$ 100 \\
\text { Burning Man ticket for } \\
\$ 380+\text { fees }\end{array}$ \\
\hline Promotion & $\begin{array}{l}\text { References to health benefits, } \\
\text { mysticism, improvement of } \\
\text { the self and authentic } \\
\text { nonwestern cultural } \\
\text { components / special sales } \\
\text { promotions }\end{array}$ & $\begin{array}{l}\text { Candles promising } \\
\text { spiritual relaxation, } \\
\text { Buddha bracelet for } \\
\text { good fortune, rose } \\
\text { quartz and ruby gems } \\
\text { that help develop } \\
\text { self-love, self-esteem } \\
\text { and self-confidence / } \\
\text { free tickets for Burning } \\
\text { Man festival }\end{array}$ \\
\hline Place & $\begin{array}{l}\text { Conventional and specialized } \\
\text { stores, intense use of the } \\
\text { Internet and social media }\end{array}$ & $\begin{array}{l}\text { Bookstores, vintage } \\
\text { shops, gift shops, } \\
\text { massage parlors, } \\
\text { specialized websites }\end{array}$ \\
\hline Consumer & $\begin{array}{l}\text { Middle to high age, affluent, } \\
\text { high-educated, female }\end{array}$ & $\begin{array}{l}\text { Baby boomers, } \\
\text { Generation } \mathrm{X} \text {, business } \\
\text { professionals and the } \\
\text { retired }\end{array}$ \\
\hline
\end{tabular}

As it is seen on Table II, the products of new age spirituality can be as diverse as goods, services, places, events and even people. Popular attractions of spiritual tourism (e.g. Byron Bay in Australia) and hip events such as Burning Man portray the extent of this phenomenon. Watkin's list of 100 most spiritually influential people provides a rich list of spiritual leaders, philosophers, politicians, TV personas and writers [21]. New age spirituality is also used in marketing as a value-adding utility. Honda offers one of its car models by referring to a well-esteemed Zen teaching, "peaceful simplicity" [22]. The utility of spirituality indeed helps businesses offer their products with high profit margins. Moreover, health benefits, aura of mysticism and claims of self-improvement are added to the spiritual utility, making such products more attractive for consumers. Given the fact that spiritual market is still a niche market and the nature of spiritual products is quite diversified, the Internet seems to be a popular medium for spiritual marketing.

Baby Boomers and Generation $\mathrm{X}$ living in western societies are said to have led the search for spirituality. According to Martin Marty, a professor of religion and the author of more than 60 books on American religion, Baby Boomers are trying to resolve the larger issues of life and death as they age [23], and this seems to explain why the leading segment buying spiritual and religious books is Baby Boomers. Montgomery et al. [24] conducted a research study on Baby Boomers and Generation $\mathrm{X}$ and found that spirituality is more important to women than it is to men. Voight, Brown and Howat [25] carried out a study including tourists in search for spiritual wellness. This segment is more likely to have obtained higher levels of education, constituting the highest proportion of respondents aged 55 and over. In conclusion, the general spiritual consumer is thought to be female, middle to high age, well-educated and high affluent.

\section{DISCUSSION AND DIRECTIONS FOR FUTURE RESEARCH}

In the midst of intense globalization and capitalization around the world, the situation in other societies with different cultural dynamics seems to be a contemporary research subject. Gaitanidis [26] provides some hints about this inquiry, indicating that Japan is experiencing a new age spiritual boom as a result of globalization and failing national economy. Given the fact that Japan is a developed country with high life-expectancy and high level of spirituality, this trend in Japan does not look quite surprising. Yet, the situation in emerging economies with young populations could be deemed an interesting topic to explore. The mutual interaction between Islam and spirituality is another worthy subject to look into. Islam is known to have been excluded from the fusion of religions in the West. But how will the western-originated spirituality affect Islamic states? Do/will some consumers in such countries adopt spiritual lifestyles or consume spiritual products under the effect of globalization?

As western countries age, niche markets in these countries could grow to a greater extent, requiring more attention for present and in the future. Furthermore, as science progresses and cultures converge to one another due to globalization and technological improvements, it is expected that the power of traditional religion institutions will continue to diminish. Such changes in western and global context could show people different paths of believing. With new scientific discoveries including space travels, new forms of spiritualties could emerge. From a pessimistic perspective, a possible World War originating from religion clashes could create a new paradigm, a new Enlightenment phase, freeing people from their traditional values that religion and culture dictate. In any case, new age spirituality or the alike is very likely to find a place in the future, so it is the duty of marketing scholars to examine this phenomenon timely and thoroughly. 


\section{REFERENCES}

[1] W. C. Roof and L. Gesch, Boomers and the Culture of Choice: Changing Patterns of Work, Family and Religion in Contemporary America, in N. Ammerman and W.C. Roof (Ed.), Work, Family and Religion in Contemporary America, Routledge, pp. 72, 1995.

[2] J. E. Myers, "Wellness through the lifespan," Guidepost, vol. 23, pp. 11, 1990.

[3] P. V. der Veer, "Spirituality in modern society," Social Research, vol. 76, no. 4, pp. 1097-1120, 2009.

[4] M.-F. Bruneau, Women Mystics Confront the Modern World, New York: State University of New York Press, 1998.

[5] C. Campbell, The Easternization of the West: A Thematic Account of Cultural Change in the Modern Era, London: Paradigm Publishers, 2007.

[6] J. Carrette and R. King, \$elling Spirituality: The Silent Takeover of Religion, London and New York: Routledge, 2004.

[7] G. Davie, Religion in Britain Since 1945, Oxford: Blackwell, 1994.

[8] R. Elliott, "Existential consumption and irrational desire," European Journal of Marketing, vol. 31, pp. 285-96, 1997.

[9] T. Jackson "Consumer culture as a failure in theodicy," in Proc. Conference on Consumption, Christianity, Creation, Sheffield Hallam University, 2002, pp. 106-124.

[10] T. F. Stillman, F. D. Fincham, K. D. Vohs, N. M. Lambert, and C. A. Phillips, "The material and immaterial in conflict: Spirituality reduces conspicuous consumption," Journal of Economic Psychology, vol. 33, pp. 1-7, 2012.

[11] D. Shaw and J. Thomson, Spirituality and Ethical Consumption, in T. Cooper (Ed.), Consumption, Christianity and creation. Sheffield, England: University of Sheffield, 2002.

[12] S. Pace, "Does religion affect the materialism of consumers? An empirical investigation of Buddhist ethics and the resistance of the self," Journal of Business Ethics, vol. 112, pp. 25-46, 2013.

[13] L. L. Lapierre. (1994). A model for describing spirituality. Journal of Religion and Health. [Online]. 33(2). pp. 153-161. Available: http://www.jstor.org/stable/27510796

[14] G. Redden, "The new agents," Journal of Consumer Culture, vol. 2, no. 1, pp. 33-52, 2002.

[15] J. Rindfleish, "Consuming the self: new age spirituality as 'social product' in consumer society," Consumption Markets and Culture, vol. 8, no. 4, pp. 343-360, 2005.
[16] D. Shaw and J. Thomson, "Consuming spirituality: the pleasure of uncertainty," European Journal of Marketing, vol. 47, no. 3-4, pp. 557-573, 2013.

[17] S. Kale. (2006). Consumer spirituality and marketing. In Asia-Pacific Advances in Consumer Research. Sydney. [Online]. Available: http://www.acrwebsite.org/volumes/ ap07/13027.pdf

[18] S. Bruce, God is Dead, Oxford: Blackwell, 2002.

[19] W. Waterschoot and T. Foscht, The Marketing Mix - A Helicopter View, in M. J. Baker and M. Saren (Ed.) Marketing Theory: A Student Text, $2^{\text {nd }}$ Edition, pp. 185-207, Thousand Oaks, CA: Sage, 2010.

[20] B. Lauterborn, "New marketing litany; Four P's passe; C-words take over," Advertising Age, vol. 26, 1990.

[21] Watkins Website. Watkins' Spiritual 100 List for 2013. [Online]. Available: http://www.watkinsbooks.com/review/watkins-spiritual-100-list-2013

[22] J. W. Smith, "Marketing that's good for the soul," Marketing Management, pp. 52, January/February 2003.

[23] ABC News Website. (2013). What Religious Books Say about Us. [Online]. Available: http://abcnews.go.com/US/story?id=95656\&page $=1$

[24] R. D. Montgomery, M. A. Mitchell, D. L. Bauer, and G. B. Turner, "A changing marketplace: Marketing religion and spirituality to Generation X," Journal of Ministry Marketing and Management, vol. 6, no. 1 , pp. $35-51,2000$.

[25] C. Voigt, G. Brown, and G. Howat, "Wellness tourists: in search of transformation," Tourism Review, vol. 66, no. 1, pp. 16-30, 2011.

[26] I. Gaitanidis, "At the forefront of a 'spiritual business': independent professional spiritual therapists in Japan," Japan Forum, vol. 23, no. 2, pp. 185-206, 2011.

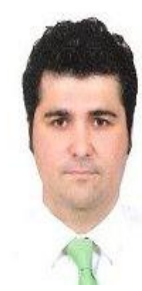

Emre Basci is currently working as a research assistant at Anadolu University of Eskisehir in Turkey and pursuing two $\mathrm{PhD}$ degrees in marketing and sociology. He received his master of science degree at Baruch College of New York City University, and his research interests are critical marketing, consumer behavior, consumption sociology and immigration. 